M. YoNOUS JAMI

Kırıkkale University, Turkey

ISMAIL GÖKDENIZ

Kırıkkale University, Turkey

\title{
The Role of Universities in the Development of Entrepreneurship
}

\begin{abstract}
In the current international competitive environment, the production of innovation is more complicated than companies, individually or as a group, or researchers who work individually or collectively can handle alone. In other words, the production of innovation requires a system of national support and pragmatism delivered in such a way that in addition to firms, other social institutions, such as higher education institutions, play a fundamental role. In response to these new expectations, these institutions have pushed to introduce internal change and evolution of interaction with the socio-economic environment, resulting in the emergence of a new generation of entrepreneurial universities. As knowledge is increasingly becoming an important component of innovation, universities, as producers of knowledge and its publication, play a wider role. The emergence of the entrepreneurial university is, in fact, a response to the growing importance of knowledge in a national and regional system of innovation and for the university, as an institution that is the source of its transfer and technology, it is economically advantageous. In the last two decades, governments around the world have seen the potential of universities to behave in an innovative way to promote the national interest, despite differences in academic and industrial systems. This paper examines the factors influencing an approach to the entrepreneurial university, its definition and concept, and investigates examples of entrepreneurial activities.
\end{abstract}

Keywords: entrepreneurship; government; innovation; social institution; university

Received: 25 June 2019

Accepted: 10 February 2020

\section{Suggested citation:}

Jami, M.Y., Gökdeniz, I. (2020). The Role of Universities in the Development of Entrepreneurship. Przedsiębiorczość - Edukacja [Entrepreneurship - Education], 16(1), 85-94. doi: 10.24917 /20833296.161.7

\section{Introduction}

Unemployment is one of the biggest social and economic problems of our time and is increasing despite all efforts by governments and various organisations to reduce it (Thurik et al., 2008). 
Due to the importance and role of entrepreneurship and entrepreneurs in the national development processes over the past decade, universities in developing and advanced countries have implemented a variety of training and research programs for the education and training of entrepreneurs according to their needs and facilities (Pihie, 2009). In other words, as the economy of a country, its laws and regulations, and the needs of the labour market are changing, higher education systems are also trying to make changes. They do this in their programs to coordinate themselves with the economic development of the labour market because the goal of implementing an entrepreneurial plan is to educate students who, after graduation, can create new jobs with innovation and initiative (Acs, 2006).

Business literature and entrepreneurship education show that entrepreneurship supports the theoretical ideas that, according to some authors, show improvements in work performance and the encouragement of the workforce to become involved. Moreover, an educational system that reflects individual skills and creativity, will have a positive impact on entrepreneurship which, as a discipline itself, will be a viable investment that will lead to advancement (Kirby, 2006). Studies have shown that entrepreneurship educational programs have a positive and significant impact on entrepreneurial goals, the desirability of access to different types and entrepreneurial related competition (Pihie, 2009).

Dynamic universities are those which value entrepreneurship and can integrate professional and managerial values into it (Balaban, Özdemir, 2008). In this era, entrepreneurial education in the universities of developed and developing countries is on the rise; mainly designed to create academic experience and train in entrepreneurial characteristics. These programs are usually aimed to produce students who apply these new ideas (Odabaş1, 2006). In these programs, various educational methods are used to improve the skills of students to enter the labour market and establish business companies, keeping in mind that a university which aims to educate entrepreneurs should be a flexible, efficient, creative and innovative organisation so as to be able to adapt to changes and not lose opportunities in various fields (Çetin, 2007).

University outcomes should be in accordance with national requirements and lead to innovations that help improve the general conditions of the society. Obviously, achieving this goal requires the provision of the necessary fields and modifications compatible with this new mission (Landstrom, 2010).

\section{The importance and need for entrepreneurship training in universities}

Entrepreneurship is gaining importance and, seen as the driving force of the economy, has caused an acceleration in entrepreneurship research. One of its main topics is entrepreneurship education (Odabaş1, 2006). The starting point of the research was whether entrepreneurial skills exist at birth or are acquired later. According to this, different prospects can be developed by adding what is learned from schools, education programs and universities to features they already have, thus gaining awareness of areas of knowledge (Acs, 2006). This may increase their chances of becoming successful entrepreneurs. Creative, critical and analytical thinking skills can be developed and entrepreneurship can be encouraged with the help of the knowledge and skills gained during the education process (Valerio, Brent, Robb, 2014).

In the past, entrepreneurship was based on material resources and experience, but since the early 1990s, the phenomena of knowledge-based innovation and the knowledge-based 
economy have developed and interacted with each other; and in fact, the main reason for the emergence of a knowledge-based economy has been the appearance of innovation and knowledge-based entrepreneurship (Arikan, 2002). Entrepreneurship training in some countries, regardless of culture and religion, shows that together with exploration it can develop and train entrepreneurs (Güney, 2008). Because of its core features, such as human capital in the form of students and faculty members, the university is the right place for knowledge-based innovation; hence universities can be entrepreneurial as they are the most important source for the production and dissemination of new knowledge. By referring to the information available on entrepreneurial universities in developed and developing countries, the importance of education and research systems in developing and educating digital entrepreneurs is more pronounced (Balaban, Özdemir, 2008). Today, entrepreneurship education courses based on information and communication technology have not only opened a place in the curriculum for different educational levels from elementary to high school but have also been considered in the curriculum in various academic fields (Kirby, 2006).

The main goal of entrepreneurship education is set up and running businesses in educational centres to assist learners to realise their capacity to express themselves and moreover, learn to apply their knowledge in practice, identify and use available opportunities, and cooperate (Matlay, 2008).

The entrepreneurial university combines its three main goals: education, research and service to the country (Bilge, Bal, 2012). According to educational institutions, this means creating entrepreneurial competition among university members and actively producing and implementing academic knowledge for the entrepreneurial environment while helping communities inside and outside the university. This supports the transfer of knowledge in three ways:

- Knowledge sharing, which involves acceptance of the industrial expansion produced by the economic implications of academic research through standardised communication and education; usually has no specific legal barriers to the use of this knowledge (Kirby, 2006).

- Knowledge production, which involves methods of providing academic services, collecting and participating in the creation and expansion of intellectual capital and the secrets of commerce.

- Intervention in knowledge, which means the involvement of universities in achieving optimal outcomes (Pihie, 2009).

\section{The entrepreneurial university}

It has been argued that the university should focus only on academic affairs with two missions: first excellent research and second the transfer of knowledge; in addition to the prevailing notion that a university is neutral and independent of industry and business. But in the new perspective, the university is regarded as the main source of investment in new technology, and sometimes even as a development engine for society (Pihie, 2009). These new tasks are considered as the third mission of a university, and some even seek to establish entrepreneurship universities. Therefore, it can be admitted that the current expectation of universities is to take responsibility for innovations and economic growth for each region and nation besides research and education (Cleary, 2002). 
In order to provide successful entrepreneurship education, it should not be limited to courses and should be supported intensively by extramural activities. It is seen that units supporting these activities have started to be structured into universities and the most common are entrepreneurship clubs (Valerio, Brent, Robb, 2014). The fact that such clubs are predominantly located in universities shows that importance is given to activities to promote entrepreneurship, to develop an entrepreneurial spirit among students and to give them an entrepreneurship perspective ( $\mathrm{Hu}, 2009)$.

Many academic institutes have established courses at the graduate level. Entrepreneurship centres have been established in order to collaborate in a wide range of activities; the establishment of education for the development of future entrepreneurs, the link between university education, and the success of economic activities and new partnerships, have been the subject of discussion in the academic forum (Matlay, 2008).

The United Nations Educational, Scientific and Cultural Organization (UNESCO) described modern universities in a global prospect for higher education for the $21^{\text {st }}$ century, as follows:

"It is a place where entrepreneurial skills in higher education are developed to facilitate graduates' capabilities to become job creators" (Delors, 1998).

According to this statement, universities are not merely a place for learning; it is no longer somewhere only to do research projects in the pursuit of the economic goals of industry; but, in addition to continuing all of these, it has the task of training individuals and firms to create new jobs. A graduate of an entrepreneurial university is no longer merely a person with academic and applied knowledge, not an individual who is just attracted to work in a manufacturing or service firm after graduation (Matlay, 2008) but a person (real or legal) who innovates in the workplace, regardless of their position, always seeing new horizons, stepping into paths which others have not seen, or even if they have, have not had the audacity to enter. The entrepreneurial university offers graduates to a country which uses their knowledge along with applied research in order to create new jobs with innovation (Mitra, Matlay, 2004).

\section{Entrepreneurship education and the role of academic centres}

In the late 1950s, Japan was the first country to start working to promote entrepreneurship culture at 'high school' level; and soon it was drawn up to the level of universities (Landstrom, 2010). Between 1970 and 1992, more than 900 industrial innovations were undertaken by entrepreneurs that raised Japan's position in the global economy. Entrepreneurship education directly affects the quantity and quality of entrepreneurship in a society (Valerio, Robb, 2014), which is why in many countries, especially advanced ones in which obstacles have been overcome as far as possible, governments have tried to encourage its maximum potential. The training of small producers is very important. By implementing this policy, various goals such as recognising opportunities and how to exploit them, familiarising new technical knowledge and its application, along with new scientific, managerial and commercial methods can always be pursued (Bilge, Bal, 2012; Lekoko, Rankhumise, Ras, 2012). Education can be long-term (such as high school education and beyond) or short-term such as occasional lectures (Peters, May, 2004). 
There are four categories of research in entrepreneurship:

- Studies of the characteristics of entrepreneurs.

- Studies of the mechanisms for the formation of new companies.

- Studies of the relationship between entrepreneurs and the community.

- Studies of teaching, the methodology of research and the role of government in entrepreneurship.

In the past, it was a commonplace that entrepreneurial characteristics, such as innovation and risk-taking, are inherent at birth. So the basic assumption was that entrepreneurs are not educated and developed through training (Mitra, Matlay, 2004). Today, however, entrepreneurship has been identified as an academic discipline and like any other, entrepreneurial science has models for learning. Entrepreneurs learn in exactly the same way; not only from their mistakes and informal educators but also through formal education (Valerio, Brent, Robb, 2014). Books and courses on new business formation are growing rapidly (Solomon, 2007). In addition to books and courses, new training programs have been designed to fill the gap for entrepreneurs who are currently pursuing their business. Educational programs work on the assumption that if only suitable and effective tools for linking resources from universities, technical schools and colleges to a new business community can be found, then industrial initiatives can really be strengthened (Zaharia, Gibert, 2005). According to a study on entrepreneurship students at the University of Baylor in 1982, it was believed the emphasis should be on higher education; followed by an emphasis on management, while human relations and marketing courses were also very important for students (Mitra, Matlay, 2004). For the first time in 1973, the University of Calgary received a license to establish a master's degree in entrepreneurship which was considered one of the main fields (Harris, Gibson, 2008). In June 1985, the university made an assessment on the results of one of its entrepreneurship training courses, which was held between June and December 1984; out of 65 students, 50 participated in this assessment. This training course cost the university about USD 75,000 (Peters, 2004). However, the experience of the University of Calgary shows that small investments like this in the training of small business entrepreneurs led to a surplus-value of about USD 1,000,750. In addition, it has had a huge impact on creating employment opportunities and facilitating capital formation (Hannu, 2000). According to the contents of entrepreneurship courses, an appropriate platform for the growth and development of entrepreneurs includes:

- Education in creativity from primary to university level, even in a $\mathrm{PhD}$ for all fields such as technical, medical, economic and others.

- Revision of educational systems, methods of teaching and evaluation of students to enhance the spirit of creativity.

- Raising the need for individuals to progress through direct and indirect training.

- Entrepreneurship education and identification of entrepreneurs in society, annually, by an expert group; moreover, their introduction and encouragement into a country or region through mass media and by awarding prizes by top-ranking national officials.

- Formation of an Entrepreneurs Association for the purpose of communication, cooperation, and collaboration, promotion of entrepreneurship culture through cultural institutions and mass media.

- Establishing entrepreneurship development centres for planning, training, research and advising on entrepreneurship.

If new solutions are looked for, courses should be designed in such a way that 
entrepreneurs would be able to grow. In most cases, centralised decision-making management is against the spirit of entrepreneurship (Ertuna, Gürel, 2001), it grows best where the focus is not at a full-scale and today entrepreneurship is taught from a young age. It seems that without the knowledge and skills of entrepreneurship, having just an idea is not enough and could lead to failure (Güney, 2008).

\section{Challenges}

Entrepreneurial training and related research now face numerous challenges:

- Challenges in creating research measurements to assess the effectiveness of entrepreneurship.

- Challenges in the content and practices of entrepreneurship education.

- Challenges in the quality of entrepreneurship instructors.

- Challenges in accepting entrepreneurship education in universities by business.

- Challenges in creating a general corpus of knowledge.

- Challenges in the effectiveness of teaching methods.

- Challenges in the learning needs of entrepreneurs who are working in line with the life cycle of a business that is currently underway.

In 1991, research into entrepreneurship education as a new discipline was considered, such as developing research methods to evaluate the effectiveness of entrepreneurship education, content and entrepreneurship education methods (Zaharia, Gibert, 2005).

By 1991, there were four major categories of entrepreneurship education courses (Peters, May, 2004):

- First

Plans for entrepreneurship awareness and orientation. The purpose of these courses was to raise awareness and understanding of entrepreneurship as a career choice for individuals from all social strata. These programs are taught at elementary, middle and high school levels to increase the motivation and desire of students to become entrepreneurs.

- Second

This category includes training programs that cover the development of companies. These programs are tailored to each country's specific requirements.

- Third

These courses are designed for the growth and survival of entrepreneurs and small companies, which includes those already existing. The training requirements in these programs are very diverse.

- Fourth

These are entrepreneurship education development programs which include new teaching methods and define new student roles. Another purpose is to educate and expand the number of teachers among those involved in entrepreneurship education.

\section{Entrepreneurship and university strategies}

With the widespread developments that are taking place in the present time in the international environment, particularly developments that are taking place in the industrial and IT communities, it seems that there are a lot of strategic changes going on in different dimensions (Tağraf, Halis, 2008). Changes in status lead to a change in strategic direction. 
The future success of universities depends on their ability to respond to the changes. Universities have to adopt the concept of entrepreneurship in order to maintain their position in the production of knowledge (Ertuna, Gürel, 2001).

To express the world's condition more explicitly and transparently, it can be found in the form of three revolutions: digital, internet and entrepreneurial, all of which have played a significant role in the development and growth of developed countries (Ertuna, Gürel, 2001). The future for value-creating countries is in business which results from a combination of these three revolutions (Peters, May, 2004). It is now assumed that the role of a university is in the value creation and the preparation of human resources in the area of the three revolutions mentioned above.

\section{Conclusion}

Entrepreneurship can be learned through experience and its transfer, but promoting it is not easy. Often the most important characteristics of entrepreneurship, such as the use of new opportunities, trust, the creation of work networks and projects, are features that cannot easily be understood and converted into recommendations and instructions. Today, many young people studying at universities and science centres are hoping to enter the "labour market" as soon as they graduate. The term "labour market" is a very sensitive term, and young people's perception of this phrase is considered one of the most important factors in the future of a country. Unfortunately, today "labour market" in the minds of many young people and students is a series of pre-set posts; in other words, it is a series of "prefabricated chairs" waiting for them. But the viewpoints of entrepreneurs on employment will, to a large extent, diminish the problems of young people in confronting the future. Such a view can be achieved by the cultural changes necessary for the development of entrepreneurship.

Organising events such as conferences, seminars and competitions, and bringing in speakers to share their experiences and making recommendations, can be considered as an indicator of this situation. Universities not only promote innovative ideas but also play a role in the implementation of these ideas. The existence of units such as Technology Transfer Offices and Incubation Centres and the opening of offices in universities in techno-cities indicate that transferring the information produced to real-life applications and commercialisation is given importance.

It is believed that for entrepreneurship to improve, the educational system should grow courageous and daring in decision-making. When graduates are offered industrial fields for themselves or offered to use legal facilities in technical and other fields, there is usually a lack of confidence; meaning, they do not have the courage to risk and take advantage of the legal benefits and facilities, and often seek paid job opportunities. If entrepreneurship is to become a serious matter, the educational system should be directed towards training graduates with entrepreneurial characteristics. Of course, the family plays a role, but the main role may be the educational system, especially in postgraduate degrees and above.

Being connected with the world outside the university is very important for expectations and needs. Therefore, the diversity of extramural activities, which are an integral part of entrepreneurship education, will ensure that the necessary arrangements are made in a timely and correct manner. 
University graduates must be encouraged to think creatively. The establishment of entrepreneurship and lifestyle education centres in difficult economic conditions, training in positive thinking and avoidance of negative thinking, perseverance and creativity to eliminate existing barriers, and acquiring the necessary skills, are some of the features that need to be addressed. Hopefully, in the future, schools for both managers and students would be set up and if governments create the necessary conditions, the real potential would be identified and groundwork for training could be created in order to move faster towards entrepreneurship. The role of the government in setting up entrepreneurship is very significant; the most important steps that it can make in terms of entrepreneurship and employment are the following:

- Producing information about available opportunities.

- Promoting entrepreneurship culture.

- Rebuilding work culture and empowering the workforce.

- Maintaining the rights of innovators, so that initiators do not imitate each other.

It is commendable that universities have started restructuring into the field of entrepreneurship education and shown a considerable improvement in a short time. The fact that the importance given by universities to entrepreneurship education, which is considered as the driving force of the economy, continues to increase and that they will come to be more effective in this regard will contribute positively to an increase in employment and economic welfare.

Finally, here are some effective measures to make universities more entrepreneurial:

- Providing financial, information and management support.

- Identifying legal, political, financial, administrative, and cultural constraints and trying to remove them.

- Introducing proper planning and application of the experiences of successful countries.

- Holding seminars and entrepreneurship workshops.

- Cultivating and promoting the entrepreneurial spirit.

- Organising entrepreneurship training in different dimensions.

- Recognising the necessary support and appreciation of entrepreneurs.

- Conducting necessary research on entrepreneurship.

- Expanding technology development centres.

\section{References}

Acs, Z.J. (2006). How is Entrepreneurship Good for Economic Growth?. Innovations: Technology, Governance, Globalization, 1(1), 97-107.

Arikan, S. (2002). Girişimcilik Temel Kavramlar ve Bazı Güncel Konular. Ankara: Siyasal Kitabevi.

Balaban, Ö., Özdemir, Y. (2008). Girişimcilik eğitiminin girişimcilik eğilimi üzerindeki etkisi: Sakarya Üniversitesi örneği. Girişimcilik ve Kalkınma Dergisi, 134-148.

Bilge, H., Bal, V. (2012). Girişimcilik Eğilimi: Celal Bayar Üniversitesi Öğrencileri Üzerine Bir Araştırma. Süleyman Demirel Üniversitesi Sosyal Bilimler Enstitüsü Dergisi, 16, 131-148.

Çetin, M. (2007). Bölgesel Kalkınma ve Girişimci Üniversiteler. Ege Akademik Bakış, 7(1), 217-238.

Cleary, J. (2006). The Entrepreneurial University and the Learning Economy in a Regional Context. Retrieved from: http://www.aair.org.au/jir/2002Papers/ Cleary.pdf

Delors, J. (ed.). (1998). International Commission on Education for the Twenty-first Century. Paris: UNESCO.

Ertuna, Z.I., Gürel, E. (2001). The moderating role of higher education on entrepreneurship. Education + Training, 53(5), 387-402. 
Güney, S. (2008). Girişimcilik Temel Kavramlar ve Bazı Güncel Konular (3. Bas-kı.). Ankara: Siyasal Kitabevi.

Hannu, L. (2000). Entrepreneurship and the Characteristics of the Entrepreneurial Personality. International Journal of Entrepreneurial Behaviour \& Research, 6(June), 295-309.

Harris, M.L., Gibson, S.G. (2008). Examining the entrepreneurial attitudes of US business students. Education + Training, 50(7), 568-581.

Hu, M.Ch. (2009). Developing Entrepreneurial Universities in Taiwan: the Effects of Funding Sources. Science, Technology \& Society, 14(1), 35-57.

Kirby, D. (2006). Creating Entrepreneurial Universities in the UK: Applying Entrepreneurship Theory to Practice. Journal of Technology Transfer, 31, 599-603.

Lekoko, M., Rankhumise, E.M., Ras, P., (2012). The effectiveness of entrepreneurship education: What matters most?, African Journal of Business Management, 6(51), 12023-12032.

Landstrom, H. (2010). Pioneers in Entrepreneurship and Small Business Research (1. Baskı.). New York: Springer.

Mitra, J., Matlay, H. (2004). Entrepreneurial and vocational education and training: lessons from Eastern and Central Europe. Industry and Higher Education, 13(1), 53-69.

Matlay, H. (2008). The impact of entrepreneurship education on entrepreneurial outcomes. Journal of Small Business and Enterprise Development, 15(3), 382-396.

Odabaşı, Y., (2006). Değişimin ve Dönüşümün Aracı Olarak Girişimci Üniversite. Girişimcilik ve Kalkınma, 1(1), 87-104.

Peters, M.A., May, T. (2004). Universities, Regional Policy and the Knowledge Economy. Policy Futures in Education, 2(2), 263-277.

Pihie, Z.A.L. (2009). Entrepreneurship as a career choice: An analysis of entrepreneurial self-efficacy and intention of university students. European Journal of Social Sciences. 9(2), 338-349.

Solomon, G. (2007). An examination of entrepreneurship education in the United States. Journal of Small business and Enterprise Development, 14(2), 168-182.

Thurik, A.R., Carree, M.A., van Stel, A., Audretsch, D.B. (2008). Does self-employment reduce unemployment? Journal of Business Venturing, 23(6), 673-686.

Tağraf, H. Ve, Halis, M. (2008). Üniversitelerdeki Girişimcilik Eğitiminin “Girişimsel Öz Yetkinlik”. Algısı Üzerindeki Etkisi: Bir Araştırma, Girişimcilik ve Kalkınma Dergisi, 3(2), 91-107.

Valerio, A., Brent, P., Robb, A. (2014). Entrepreneurship education and training programs around the world. Washington DC: The World Bank.

Zaharia, S.E., Gibert, E. (2005). The Entrepreneurial University in the Knowledge Society. Higher Education in Europe, 30(20), 31-40.

M. Yonous Jami, PhD student, holds an MA and PhD in Business Administration from Kirikkale University. His career involves teaching and conducting research in entrepreneurship and strategic management at Kirikkale University. He can speak English, Turkish and Persian. His studies in the area of entrepreneurship, Strategic Management, Artificial Intelligence and Marketing Strategies have been published in international journals.

ORCID: https://orcid.org/0000-0002-9349-8017

\section{Address:}

Kirikkale Üniversity

Institute of Social Sciences

Faculty of Economics and Administrative Sciences

Department of Business Administration

Ankara Yolu 7. Km

71450 Yahşihan/Kırıkkale, Turkey

e-mail: yonisjami@hotmail.com 
Ismail Gökdeniz, Kırıkkale University, Assistant Professor, Department of Business Administration. He holds an MA and two PhDs in public administration and business administration from Selcuk University in Turkey. He teaches scientific research and publication ethics, international human resources management, public and private sector structure and entrepreneurship as well as financial management at Kirikkale University. His career involves teaching and conducting research at both Selcuk University and Kirikkale University. His research in the area of entrepreneurship, SMEs, entrepreneurship and financial management have been published in international journals. Asst. Prof. Ismail Gökdeniz is a certified management consultant.

ORCID: https://orcid.org/0000-0003-4342-0200

\section{Address:}

Kirikkale Üniversity

Institute of Social Sciences

Faculty of Economics and Administrative Sciences

Department of Business Administration

Ankara Yolu 7. Km

71450 Yahşihan/Kırıkkale, Turkey

e-mail: yonisjami@hotmail.com 